\title{
The role and importance of environmental administration in the protection against environmental damages
}

\author{
Erika László
}

https://doi.org /10.33542/VSS2019-2-07

\begin{abstract}
In this study, the author presents the central, regional and local levels of environmental administration in Hungary and their tasks. Through two specific examples (the Danube Flood and the 2010 Kolontár Red Sludge Disaster), she analyzes the incidents damaging the environment, their consequences and impacts. She also proves that the cooperation between municipalities and regional environmental and disaster management bodies is inevitable. She studies the role played by the environmental administration in the protection and makes suggestions for improving the efficiency of protection. In the context of the two incidents, she analyzes the possibilities of the environmental administration in the protection against environmental damages and makes recommendations on its development.
\end{abstract}

Keywords: environment protection, environmental administration, public administration, red sludge disaster, flood

\section{Introduction}

Today's environmental problems have a number of tasks for public administration professionals. The protection of our built and natural environment is a two-way task, because it is not always necessary to protect the environment from the people, but sometimes the other way around. For example, in many cases, when performing flood-related tasks it is necessary to protect the built environment, while in an industrial accident, both built and natural environments are affected. Protecting the environment has become a social task today, with protection organizations, citizens, and environmental administration officials having an outstanding responsibility alike. It is therefore important that the persons performing environment protection in public administration have the greatest possible theoretical and practical knowledge. In Hungary, the tasks of environment protection and environmental management are planned, organized and implemented in the framework of environment administration. Let us examine the Hungarian environmental administration system. 


\section{Hungary's environmental administration}

Environmental administration is implemented in Hungary within the framework of public administration and is aligned with public administration, divided into three levels. These are presented below:

\section{Ministerial, central level}

In Hungary, the State Secretariat for the Environment of the Ministry of Agriculture is the top state administration body responsible for environment protection. There are 10 National Park Directorates in the country, managed by the Minister responsible for the environment. Deputy State Secretariats for Nature and Environment Protection, which manage 3 departments each, are separated within the State Secretariat for the Environment. The State Secretary for the Environment is responsible for the professional management of the Pest County Government Office acting as the National Environmental and Nature Protection Authority, the District Offices (regional environment and nature protection authorities) acting in the capacity of environmental and nature protection, and for the regional laboratories operated by county government offices acting in the capacity of environment protection. The Deputy State Secretary for Environment Protection is also responsible for the management of the Hungarian Meteorological Service.

The Deputy State Secretary for Nature Protection exercises property rights over some background institutions, such as the Herman Ottó Institute Nonprofit Ltd. and the Hortobágy Nature Conservation and Gene Conservation Nonprofit Ltd. It also manages the Livestock Gene Conservation Center, the Plant Diversity Center and the National Park Directorates.

The Ministry for Innovation and Technology, including the State Secretary for Energy and Climate Policy and the State Secretary for Sustainability also deal with environmental issues.

The work of the State Secretaries is supported by the Deputy Secretariats responsible for Energy, Climate Policy, Sustainable Development, Operational Programs for Environment and Energy Efficiency. Their tasks include, inter alia, performing Hungarian, Community and international tasks in the waste management area, regulating priority public services (water utilities, waste management-related public services), performing governmental and professional tasks related to electromobility, and managing targeted allocations for achieving energy and climate policy goals. They also provide for the implementation of the Environment and Energy Operational Program, performing Hungarian, Community and international tasks in the climate policy area, the utilization of renewable energy resources and in the field of energy efficiency, the elaboration and implementation of climate policy strategies, and of the National Energy Strategy and the Action Plans for its implementation, etc. 
Water administration is also part of the environmental administration, which is the task of the Deputy State Secretary for Public Employment and Water Management, directed by the State Secretary for Public Administration of the Ministry of the Interior. The Deputy State Secretary for Public Employment and Water Management is responsible for organizing water damage prevention activities within his competence for water management, for organizing water damage prevention, for directing water management activities, and tasks related to the protection of water as an environmental element, and provides for the professional preparation of legislation relating to the protection of water as an environmental element, etc. The public health aspects of drinking and bathing water belong to the Ministry of Human Capacities. From the above it can be seen that due to the diversity of the topic, the administration can be linked to several ministries, therefore coordination has a significant role.

\section{Central directional, regional level}

As a national environmental and nature protection authority, the Pest County Government Office, and the District Offices of County government Offices as per county seat act as regional environmental and nature protection authorities - with county competence. The Érd District Office of the Pest County Government Office acts as an environment protection authority with competence with jurisdiction over Budapest, the Capital and Pest County, with district competence, the District (or Budapest District) Office of the Budapest and County District Offices act as environmental authorities. In the first instance, the regional environmental authority, and in the second instance, the national environmental authority act as environmental authorities.

In 2014, the administration and authoritative functions were separated at secondary water management level. As a water management body, the Government appointed the National Directorate General for Water and the 12 Regional Water Management Directorates. As water management authority, the Government appointed the National Directorate General for Disaster Management (NDGDM), Ministry of the Interior and at regional level, 12 regionally competent Disaster Management Directorates. The national management of the technical tasks of flood and inland water protection is performed by the National Technical Operational Staff (OMIT).

\section{Municipal, local level}

Local governments play a significant role in the implementation of local environmental tasks, which include the implementation of environment protection legislation, the fulfillment of the authoritative tasks assigned to their competence, and the elaboration of a municipal environment protection program. Municipal decrees and decisions are taken to resolve environmental issues, and they cooperate with other authorities performing environmental 
tasks. In the case of first instance decisions made at the municipal level, the regional environmental authority acts as a second instance authority.

In order to carry out its tasks related to the protection of the built and natural environment, the county government prepares the county environment protection program, takes a stand and gives an opinion on the decrees and environmental programs of the local governments. The municipal body of representatives is responsible for, among others, the elaboration of a smoke pollution alert plan, determining the rules on air pollution caused by household activities (incineration of dry leaves and garden waste) by issuing decrees, contributing to the process of identifying ecologically vulnerable areas in terms of air pollution, and for declaring certain areas to be highly protected from the aspect of noise protection, and for the designation of silence zones and the establishment of local noise protection rules. Its main tasks include in the field of water protection local water management and water damage response, flood and inland water drainage, municipal authoritative tasks related to water management, the management of rainwater in the built-up part of the settlement, the designation of the banks and shores of natural waters suitable for bathing and the associated water surface, etc.

The municipality is also responsible for performing and providing for public waste management.

The lord mayor, the mayor, the chief notary of the capital, the notary of a local government and the notary of the capital's district may act as environmental authority within a local government (in cases specified in a separate legislation). Such an environmental case could be, for example, the imposition of a waste management fine on illegally disposed of or abandoned waste, for example by the notary. In the case of protected natural areas of local importance, the notary of the local government also acts as a nature protection authority. After presenting the levels of environmental administration and their tasks, I study the types of environmental damages.

\section{Environmental damages}

Disasters can be of natural and human origin. Disasters of natural origin are the types of disasters that occur mostly without human intervention, under the influence of natural forces. Such can be a heavy rainfall, snow, ice, typhoons, tornadoes, earthquakes. Such meteorological natural phenomena can lead to floods, tsunamis, forest fires and snow emergencies, which, in many cases, lead to disasters (HORNYACSEK, 2011). It is also clear that environment protection and disaster management are closely linked.

There may also be cases where the forces of nature cause disasters due to improper human involvement in the environment (these are of man-made origin). Examples of such tasks include flood and inland water protection tasks or waste management activities that result from improper or incorrectly designed or constructed structures. I would like to present the difficulties 
of controlling this type of damages with the help of two examples in the following chapter. The basis of my study is the "history-maker" great Danube flood in 2013 in Hungary, and the red sludge disaster in 2010 in Kolontár.

\section{Danube flood (2013)}

Floods occur on the main rivers of Hungary every spring, beginning of summer, caused by precipitation and the melted snow, from the catchment area in the surrounding countries. It is important to mention that every flood wave is formed by different hydrological and meteorological factors (PETRÓ, 2017). In Hungary, floods can be considered one of the most typical environmental hazards. In 2013, several days of heavy rainfall in the Danube river basin was responsible for the flooding. The destruction of the natural and built environment during floods is always an expected incident. The primary impact is the shock wave that may cause buildings to collapse and become damaged. The natural environment is damaged, plants and animals also fall victims. Damage to roads, bridges, gateways makes transport and traffic difficult, and supplies are stalled. Because of the damages to utilities, everyday life is upset, production is lost, supply is stalled. In 2013 , all of these had to be witnessed.

The Danube runs 417-km long in Hungary, which gives tasks to many settlements during flood protection (NAGY, 2013). However, protection is not only the responsibility of the municipalities. In 2013, before the floods reached the Hungarian section, OMIT started to organize the protection. OMIT is a specialized body of the National Directorate General for Water (OVF), which is established if national coordination, a more efficient redeployment of assets and personnel becomes necessary (BALATONYI, 2018.) in case of simultaneous protection efforts by several water management directorates. During the given period, the water directorates set up their own protection units on the state protection lines and protection sections. In areas where there were not enough personnel, resources, or protection material, the shortages were eliminated by redeploying the personnel. In addition, the personnel of the municipalities concerned were reinforced by technical experts.

The professional management of flood protection was carried out by the Water Service. The main water management body directing the protection efforts, OMIT, based on the National Directorate General for Water Management, coordinated the work of the water management directorates and experts for 46 days. For the protection, the water service was responsible on the state protection lines, and the local governments were responsible for the sections belonging to them. For the sake of successful protection, the water service also took over the technical management at the municipalities. OMIT's work was supported by the Scientific Council during this period. It became clear during the protection that - especially in the upper section of the Danube - the municipal protection system had to be reorganized. The preparedness of the municipalities was not sufficient to manager such a flood. Municipalities 
had to take care of proper professional management and the basic protection of the settlements. Temporary protection structures did not provide sufficient protection, therefore, the use of permanent facilities and expert knowledge had to be introduced to receive the flood. The maximum length of the flood protection lines was $758,9 \mathrm{~km}$. On 8 June 2013, the Danube peaked at $907 \mathrm{~cm}$ at the highest level of all time (OMT, 2013). Actual protection intervention took place at 34 locations on the state protection lines and at 89 sites in 55 municipalities. The efforts in the field of flood control, the onsite work and the cooperation of the municipalities and authorities were successful. The dykes and the technical facilities built during the protection period fulfilled their tasks entirely until the end of the flood.

Overall, it can be concluded that the disaster relief, water management and environmental assistance to the municipalities and the population proved to be necessary and appropriate. It became also clear that the close coordination between the parties involved is essential in such cases, which raises the need for common exercises.

\section{The red sludge disaster}

The Kolontár Red Sludge Disaster was the largest industrial and environmental disaster in Hungary. On 4 October 2010, the north-west wall of the red sludge reservoir of Ajka Timföldgyár (MAL Ltd.), Located in Veszprém County, breached due to the heavy rainfall. More than one million cubic meters of red sludge and highly alkaline water poured over the settlements Kolontár and Devecser as a result of the dam breach (FÖLDI, HALÁSZ, 2014).

The flow full of heavy metals reached Somlóvásárhely, Somlójenő, Tüskevár, Apácatorna and Kisberzseny. During the disaster, 10 people died and 120 seriously injured (HOFFMANN, 2011). In addition to the physical destruction caused by the flood, the strongly alkaline sodium hydroxide found in the red sludge had to be responded to, causing burns on the skin in contact with it, thus having a detrimental effect on the population and the persons involved in the rescue. In addition to humans and the built environment, the alkaline-containing material caused significant damage to the wildlife. It destroyed the entire flora of the Torna Creek, the Marcal River was contaminated, and soon afterwards the dirt reached the Danube. The destruction involved flora and fauna in the water streams, arable land and backyard gardens. It had an impact on the microbiological environment, on plants and on wild and domestic animals.

The alkaline property of the material lies in the fact that the alumina content of the bauxite at the Ajka alumina plant is separated from the other components by sodium hydroxide, under strongly alkaline conditions. Bauxite is a mineral, a raw material consisting of aluminumcontaining minerals and other components such as iron and silicon compounds. Its color is red due to ferrous minerals (NÉMET, 2013). The main product thus produced is alumina, from which pure aluminium metal is produced by electrolysis. The by-product of alumina production 
is red iron with a high iron content, which contains the unaltered components of bauxite and sodium aluminum silicate (KURDI, 2011).

All levels of environmental administration played an important role in coordinating the above tasks. The industrial disaster was immediately eliminated by disaster management specialists, law enforcement agencies and the personnel of the Hungarian Defense Forces ${ }^{1}$

The size of the incident area and the complexity of the tasks to be performed required an organized management system, therefore, from 5 October 2010, an operational staff was established to coordinate the response activities elimination and the population protection tasks from NDGDM to coordinate onsite damage response tasks. The Central Transdanubian Environment and Nature Protection and Water Inspectorate (KTVF) continuously measured the $\mathrm{pH}$ value of the Torna Creek, the amount of dust in the air and the amount of pollutants in the soil. On the disaster management website, the population was informed that the regionally competent Central Transdanubian Environment Protection and Water Management Directorate (KÖVIZIG), the Western Transdanubian Environment Protection and Water Management Directorate and the North Transdanubian Environment Protection and Water Management Directorate cooperated with the local disaster management organs and health services at several response sites. During the damage elimination process, KTVF and KÖVIZIG laboratories performed continuous measurements of the living waters.

The role of public administration in the prevention and elimination of disasters is well illustrated by the fact that in the post-disaster period, the state administration made a number of amendments to the legislation, the structure of the authoritative system, and the classification of hazardous waste. The licensing authorities and competences were defined and new regulations were introduced to distinguish between waste and materials in the technological process. A part of the previous environmental regulations and obligations proved to be inadequate to prevent such a disaster. Therefore, based on the report of the Parliamentary Committee of Inquiry, the Parliament amended the statutory provisions on disaster management (KEPLI, 2011). In order to prevent the occurrence of similar incidents, the powers of the National Directorate General for Disaster Management in the field of industrial safety were augmented. As a result, a tighter control and regulatory system was established, and the cooperation with partner authorities became closer. Based on the above, it can be proved that the different levels of environmental administration and defense/protection organizations must work together closely during similar incidents, to coordinate their tasks; which should already be considered during the prevention phase.

\footnotetext{
${ }^{1}$ The $93^{\text {rd }}$ Petőfi Sándor Chemical Protection Battalion, HDF, immediately after their arrival at the incident site, started the rescue and mitigation. Their tasks included cleaning the main roads and major equipment contaminated with sludge.
} 


\section{The tasks of environmental authorities in the protection against environmental damages}

In the system of environmental authorities described above, central and regional administrations always played a prominent role. The main reason for this is that professionals with expertise and practical experience work in these areas in higher numbers. Several studies and the lessons learnt above also highlighted the fact that there are fewer environmental professionals in the local (municipal) sector, and that their experience is less diverse than the one in the central administration. Some studies also highlighted the fact that the quality of environmental responsibility and related activities is also influenced by the size of the settlements (VARJÚ, 2013). In smaller settlements with less financial potential, the sustainability of the natural environment and environmental activities are often undermined by other mandatory tasks.

According to some researches, the performance of environmental tasks is sometimes due to obligation and less intrinsically due to internal motivation.

A study on the efficiency of flood protection at the central and local levels, on the other hand, pointed out that local authorities only have information on local phenomena, the structure of the settlement, the state of the dykes/dams and the current state of water levels, and other competencies relevant to their decision, with no central control (GOLOVICS, 2015).

According to a $\mathrm{PhD}$ dissertation on the modernization of local government-level protection against floods and inland waters, during the flood and inland water protection efforts in 2010 , local governments needed assistance in protecting their own settlements. In most places, the organization and direction of disaster management and water management bodies, as well as voluntary citizens had to be implemented (BÁRDOS, 2016.).

The above thoughts would not only be relevant during flood protection but would also prevail during the resolution of other environmentally relevant problems. Municipalities would not be able to cope with floods in the future without the involvement of water management directorates, regional disaster management bodies and OMIT. In the professional management of damage elimination, central and regional mid-level management bodies gained extensive experience. Therefore, it would be important to prepare the municipalities for environmental and disaster management tasks, both in terms of personnel and equipment.

As a summary, in Hungary, environmental administration operates on three levels. Major state tasks include legislation and its enforcement, shared between central and local levels. Floods and industrial disasters, which severely damage both the natural and the built environment, are among the most significant threats. The protection of the environment is a task of the society, in which settlements play an important role. Based on the analysis of the 
literature and the two examples above, it can be clearly seen that the different levels of public administration are defined so that they are built on each other and interact with each other. Environmental, water management and disaster management authorities with no knowledge of the local conditions, cannot perform their duties and must be assisted by the local authorities. Municipalities have less financial resources, and fewer experts with specialist skills. Thus, the cooperation with national and regional authorities and defense/protection bodies resulted in the efficiency of protection. Therefore, the coordination of administrative tasks and the cooperation of regional and local authorities played an important role in both cases. In order to enable the state to respond to the threats facing the population and the local environmental problems as fast and efficiently as possible, it would be important to train and prepare the personnel and equipment related to environment protection at the local (municipal) level. Municipal administration has an important role to play in the all-round implementation of environmental tasks. In the future, the authorities will also be indispensable in the development of the cooperation between municipal and protection authorities and the citizens.

\section{References}

BALATONYI, L. 2013. Árvízvédelem (a short overview). National Directorate General for Water. http://www.ovf.hu/hu/arvizvedelem-1 (31 May 2019).

BÁRDOS, Z. 2016. Az ár- és belvizek elleni önkormányzati védekezés korszerüsitése $P h D$ dissertation. Budapest, 2016. National University of Public Service (NUPS), Military Technical Doctoral School.

FÖLDI, L. HALÁSZ, L. 2014. Környezetmérnökök katasztrófavédelmi feladatai. https://www.tankonyvtar.hu/hu/tartalom/tamop412A/2011-

0089_09_katasztrofavedelmifeladatok/ch05s05.html (02 June 2019).

HOFFMANN, I. 2011. A katasztrófavédelem aktuális kérdései. A „vörösiszap”-katasztrófa következményeinek elhárítása során szerzett tapasztalatok. MOD Zrínyi Media Nonprofit Ltd. Budapest. ISBN 9789633275245.

HORNYACSEK, J. 2011. A TELEPÜLÉSI VÉDELMI KÉPESSÉGEK A KATASZTRÓFAKIHÍVÁSOK TÜKRÉBEN. A települések katasztrófaelháritási feladatai, a végrehajtáshoz szükséges helyi védelmi képesség alapvetö területei, azok kialakitásának folyamata. BÉOTTE Budapest, 2011. ISBN: 978-963-08-2606-8 p.16.

KEPLI, L. 2011. Report: A Kolontár melletti vörösiszap-tározó átszakadása miatt bekövetkezett környezeti katasztrófával kapcsolatos felelösség feltárását és a hasonló katasztrófák jövőbeni megakadályozását célzó országgyülési vizsgálóbizottsága vizsgálatának eredményéről. https://www.parlament.hu/irom39/04795/04795.pdf (02 April 2019).

KURDI, R. 2011. Vegyipari folyékony hulladékok. https://www.tankonyvtar.hu/hu/tartalom/tamop425/0021_Vegyipari_hulladekok/ch05s02.html (02 June 2019). 
MOLNÁR, L. 2011. A katasztrófavédelem aktuális kérdései. Az MH ÖHP KOCS tevékenysége és vezetés-irányítási rendje a HKR müködésének időszakában. MOD Zrínyi Media Nonprofit Ltd. Budapest ISBN 9789633275245.

NAGY, S. A. 2013. Hidroökológia. Debrecen University, Debrecen 2013. (30 April 2019).

NÉMET, B. 2013. Ipari technológiák. Pécs Univesity, Pécs. (30 May 2019).

OMT, 2013. Az Országos Müszak Irányitó Törzs, 2013. 06.0808 .00 órakor kiadott közleménye.

http://www.vizugy.hu/print.php?webdokumentumid=723 (05 May 2019).

PETRÓ, T. 2017. Árvizek kártételei, a védekezés lehetőségei. A magyarországi nagy árvízvédelmi projektek, eszközök és technológiák alkalmazásának lehetőségei az árvíz elleni védekezés eredményes megvalósításában. PhD dissertation, NUPS, Budapest, 2017. p.51.

VARJÚ, V. 2013. Aprófalvak környezeti politikája. A falu. 2013 autumn, year XXVIII, pp 45-55. p. 9-10.

\section{Legislation}

Government Decree 232/1996. (XII. 26.) - on the rules of the protection against damages by water.

Ministry of Agriculture Instructions 2/2018. (IX. 10.) - on the Organizational and Operational Rules of the Ministry of Agriculture.

Government Decree 366/2015. (XII. 2.) - on the designation of bodies responsible for the administration of water protection and on the amendment of certain government decrees on water management issues.

Government Decree 223/2014. (IX. 4.) - on the designation of water administration and water management bodies, and of bodies performing water protection authoritative tasks.

Ministry for Innovation and Technology Instructions 4/2019. (II. 28.) - on the Organizational and Operational Rules of the Ministry for Innovation and Technology.

\section{Contact address}

Erika László

Doctoral student

National University of Public Service

Doctoral School of Public Administration Sciences

Budapest, Ludovika tér 2, 1083 Hungary

Email: laszlo.erika@uni-nke.hu 